\title{
Ruminal Fermentation and Bacterial Protein Synthesis of Whole Cottonseed Coated with Combinations of Gelatinized Corn Starch and Urea
}

\author{
J. K. Bernard, ${ }^{\star}$ J. W. West, ${ }^{\star}$ D. S. Trammell, ${ }^{\star}$ A. H. Parks, $†$ and T. C. Wedegaertner‡ \\ *Department of Animal and Dairy Science, University of Georgia, Tifton 31793-0748 \\ †Department of Large Animal Medicine, University of Georgia, Athens 30602-7385 \\ ¥Cotton Incorporated, Cary, NC 27513
}

\begin{abstract}
Four ruminally and duodenally cannulated Jersey cows were used in a $4 \times 5$ incomplete Latin square study to determine the effects of including urea in the gelatinized corn starch coating applied to whole cottonseed (WCS) on ruminal fermentation, fiber digestion, and bacterial protein synthesis. Treatments included uncoated WCS (control) and four coated WCS treatments. The coatings provided two concentrations each of gelatinized corn starch $(2.5[2 \mathrm{~S}]$ or $5 \%$ [5S]) and feed grade urea $(0.25[2 \mathrm{U}]$ or $0.5 \%$ [5U]). Treated WCS comprised $15 \%$ of the ration dry matter that was fed as a total mixed ration once daily. Ruminal $\mathrm{pH}$ and molar proportions of isobutyrate was higher and $\mathrm{NH}_{3}-\mathrm{N}$ concentrations lower for control compared with coated WCS. Molar proportions of propionate tended to be higher and valerate was lower with $2 \mathrm{~S}$ compared with 5S. Molar proportions of acetate tended to be lower, whereas butyrate was higher for $5 \mathrm{U}$ than $2 \mathrm{U}$. Nutrient intake was lower for WCS coated with 5S5U compared with 2S5U. Ruminal NDF digestibility of NDF tended to be higher with $5 \mathrm{U}$ compared with $2 \mathrm{U}$, but no differences were observed in ruminal or total tract apparent digestibility of nutrients. No differences were observed in the flow of total $\mathrm{N}$ or bacterial $\mathrm{N}$ to the duodenum, but the flow of nonbacterial $\mathrm{N}$ tended to be higher for WCS coated with 5U. Coating WCS appears to slightly alter ruminal metabolism while providing similar amounts of $\mathrm{N}$ flowing to the duodenum without altering fiber digestion.
\end{abstract}

(Key words: cottonseed, starch, ruminal fermentation, bacterial protein synthesis)

Abbreviation key: $\mathbf{2 S}=2.5 \%$ starch, $\mathbf{5 S}=5.0 \%$ starch, $\mathbf{2 U}=0.25 \%$ urea, $\mathbf{5} \mathbf{U}=0.5 \%$ urea, $\mathbf{W C S}=$ whole cottonseed.

Received October 25, 2002.

Accepted May 29, 2003.

Corresponding author: J. K. Bernard; e-mail: jbernard@tifton.cpes. peachnet.edu.

\section{INTRODUCTION}

Coating whole cottonseed (WCS) with gelatinized corn starch binds the short fibers attached to the seed coat, producing a free flowing product (Laird et al., 1997). However, coating WCS with $5 \%$ starch decreased total tract NDF digestibility and tended to decrease milk fat percentage when fed to lactating dairy cows (Bernard et al., 1999). In a subsequent trial in which WCS coated with $2.5 \%$ starch were fed to lactating dairy cows, no depression in milk fat percentage was observed (Bernard, 1999). When WCS coated with either 2.5 or $5.0 \%$ starch were subjected to in vitro mixed ruminal microorganism fermentations, concentrations of $\mathrm{H}_{2}$, lactate, and total VFA and molar proportions of propionate increased linearly and molar proportions of acetate decreased linearly (Bernard et al., 1999, 2001).

One possible explanation for these results is that the starch coating stimulates increased activity of amylolytic microorganisms over the cellulolytic microorganisms around the coated WCS accounting for the reduced fiber digestion and molar proportion of acetate and increased molar proportion of propionate. Adhesion of cellulolytic ruminal bacteria to fiber is not inhibited by rapidly fermented sugars added at concentrations up to $1 \%$ (Miron et al., 2001). Total dietary starch concentrations increase approximately $0.75 \%$ when WCS coated with $5 \%$ starch are fed at $15 \%$ of the ration DM, although the concentration of starch surrounding the coated WCS would be higher. Piwonka and Firkins (1996) reported that reduced fiber digestion may be due to the presence of a proteinaceous inhibitor when $\mathrm{pH}$ is not reduced and rapidly fermented sugars are included in the diet (Piwonka and Firkins, 1996). These researchers observed that treatment of in vitro cultures with protease prevented the reduction in the rate of NDF digestion.

Because cellulolytic microorganisms utilize ammonia as their primary $\mathrm{N}$ source, the inclusion of urea in the coating could potentially maintain or improve fiber digestion and possibly stimulate greater flow of bacterial $\mathrm{N}$ to the small intestine. In vitro mixed ruminal micro- 
Table 1. Ingredient composition of experimental diets containing whole cottonseed coated with combinations of gelatinized corn starch and urea.

\begin{tabular}{lc}
\hline Ingredient & $\%$ of DM \\
\hline Corn silage & 45.9 \\
Alfalfa hay & 13.5 \\
Whole cottonseed & 14.9 \\
Concentrate & \\
Ground corn & 12.2 \\
Soybean meal, 48\% CP & 8.4 \\
Prolak $^{1}$ & 2.4 \\
Limestone $_{\text {Mineral-vitamin premix }}{ }^{2}$ & 0.8 \\
\hline
\end{tabular}
CT)

${ }^{1}$ Marine-animal protein blend (H. J. Baker \& Bro., Inc., Stamford,

${ }^{2}$ Premix contained (DM basis) $99.07 \%$ ash; $14.27 \% \mathrm{Ca} ; 5.42 \% \mathrm{P}$; $4.96 \% \mathrm{Mg} ; 0.05 \% \mathrm{~K} ; 10.67 \% \mathrm{Na} ; 2.98 \% \mathrm{Cl} ; 0.37 \% \mathrm{~S} ; 11 \mathrm{mg} / \mathrm{kg}$ of Co; $577 \mathrm{mg} / \mathrm{kg}$ of Cu; $4,858 \mathrm{mg} / \mathrm{kg}$ of Fe; $51 \mathrm{mg} / \mathrm{kg}$ of I; $1806 \mathrm{mg} / \mathrm{kg}$ of $\mathrm{Mn} ; 13 \mathrm{mg} / \mathrm{kg}$ of Se; $1694 \mathrm{mg} / \mathrm{kg}$ of Zn; 115,240 IU/kg of vitamin A; $46,100 \mathrm{IU} / \mathrm{kg}$ of vitamin D; and $576 \mathrm{IU} / \mathrm{kg}$ of vitamin E.

organism fermentation of WCS coated with combinations of starch plus urea increased $\mathrm{pH}$ and $\mathrm{NH}_{3}-\mathrm{N}$ concentrations, but fiber digestion was not determined (Bernard et al., 2001). The objective of this study was to determine the effect of coating WCS with combinations of starch plus urea on in vivo ruminal fermentation, fiber digestion, and bacterial protein synthesis.

\section{MATERIALS AND METHODS}

Four lactating Jersey cows previously fitted with ruminal and simple gutter duodenal cannulas were used in a $4 \times 5$ incomplete Latin square study. Cows were cannulated and managed according to procedures approved by the University of Georgia Institutional Animal Care Committee. Cows averaged $298 \pm 14$ DIM, $15.0 \pm 2.9 \mathrm{~kg} / \mathrm{d}$ of milk, $4.5 \pm 1.0 \%$ fat, and $3.6 \pm 0.3 \%$ protein at the beginning of the trial. Each 14-d experimental period consisted of a 9-d adaption period followed by a 5 -d collection period.

Experimental diets are described in Table 1. One lot of WCS were processed through a modified gin stand to remove tags and lose lint before application of the experimental coatings as described by Laird et al. (1997). Treatments included an uncoated control WCS (control) and WCS coated with two concentrations of $\operatorname{starch}(2.5[2 \mathrm{~S}]$ or $5.0 \%[5 \mathrm{~S}])$ or urea $(0.25[2 \mathrm{U}]$ or $0.5 \%$ $[5 \mathrm{U}])$. Chromic oxide was included in each diet as an inert marker at the rate of approximately $20 \mathrm{~g} / \mathrm{d}$ for determining digesta flow to the duodenum and calculation of apparent digestibility of nutrients. Cows were individually fed behind Calan gates (American Calan Inc., Northwood, $\mathrm{NH}$ ) once daily in amounts to ensure $10 \%$ orts. The amount of TMR offered and orts were recorded daily. Samples of ingredients, diets, and orts were collected $3 \mathrm{~d}$ each week and DM content was determined by drying in a forced-air oven at $55^{\circ} \mathrm{C}$ for $48 \mathrm{~h}$.

Whole blood samples were collected $2 \mathrm{~h}$ after feeding by venipuncture on d 14 of each experimental period. Tubes were allowed to clot, and serum was harvested by centrifugation. Concentrations of urea $\mathrm{N}$ and glucose in serum were determined using a Boehringer Mannheim/Hitachi 912 automated chemistry analyzer (Roche Diagnostics, Indianapolis, IN).

Duodenal and fecal grab samples were collected at 12-h intervals on d 11 through 14 . Sampling time was varied by $1 \mathrm{~h}$ each day. On d 14, rumen fluid was collected at $0,2,4,6$, and $8 \mathrm{~h}$ after the a.m. feeding. Samples were immediately strained through two layers of cheesecloth, and $\mathrm{pH}$ was determined immediately. A 10-ml sample was frozen for determination of ruminal $\mathrm{NH}_{3}-\mathrm{N}$ concentrations using a specific ion electrode (Orion Research Inc., Boston, MA). A second sample (10 $\mathrm{ml}$ ) was deproteinized with $2 \mathrm{ml}$ of $25 \%$ metaphosphoric acid and frozen for VFA analysis (Supelco, 1975). An additional $200 \mathrm{ml}$ of rumen fluid was collected from each cow at each collection time for isolation of rumen bacteria. Ruminal fluid samples were composited by treatment and bacteria were isolated using a KSB continuous flow system (Kendro Laboratory Products, Newtown, CT). The bacterial isolate samples were lyophilized to dryness.

Ingredient and diet samples were composited by week and ground to pass through a 1-mm screen using a Wiley mill (Arthur H. Thomas, Philadelphia, PA). Duodenal samples were lyophilized, composited by cow, and ground to pass through a 1-mm screen. Fecal samples were dried in a forced-air oven, composited by cow, and ground to pass through a 1-mm screen. Composite ingredient, TMR, duodenal, and fecal samples were analyzed for DM, N, ash, (AOAC, 1990) NDF (Van Soest et al., 1991), and chromic oxide (Brisson, 1956). The N content of bacterial isolates was determined according to AOAC (1990). Purine concentrations in duodenal composites and bacterial isolates were determined according to the procedures of Zinn and Owens (1986) to differentiate between dietary and microbial $\mathrm{N}$ reaching the duodenum.

Nutrient intake and digestibility, blood metabolites, and $\mathrm{N}$ flow data were subjected to ANOVA using PROC GLM procedures (SAS, 1999) for a $4 \times 5$ incomplete Latin square design. Ruminal metabolite data were analyzed using PROC MIXED to account for the repeated measures. Sampling time was included in the model as a repeated effect. Contrast were included in the model for: 1) control versus coated WCS; 2) 2.5 versus $5.0 \%$ starch; 3) 0.25 versus $0.5 \%$ urea; and 4) interaction of starch and urea coatings. 
Table 2. Chemical composition of ingredients used in experimental diets (\% of DM). ${ }^{1}$

\begin{tabular}{lrrrrr}
\hline & \multicolumn{1}{c}{ Ash } & \multicolumn{1}{c}{ CP } & \multicolumn{1}{c}{ EE $^{2}$} & ADF & NDF \\
\hline Whole cottonseed & & & & & \\
0\% starch, 0\% urea & $3.4 \pm 0.1$ & $21.7 \pm 0.2$ & $19.6 \pm 0.5$ & $40.3 \pm 0.7$ & $51.9 \pm 1.2$ \\
2.5\% starch, 0.25\% urea & $3.4 \pm 0.2$ & $20.8 \pm 1.6$ & $19.6 \pm 0.6$ & $38.2 \pm 0.8$ & $52.1 \pm 1.2$ \\
2.5\% starch, 0.50\% urea & $3.3 \pm 0.1$ & $20.9 \pm 1.2$ & $19.6 \pm 0.5$ & $38.7 \pm 1.2$ & $51.3 \pm 0.7$ \\
5.0\% starch, 0.25\% urea & $3.3 \pm 0.1$ & $21.4 \pm 1.2$ & $18.6 \pm 0.8$ & $38.5 \pm 0.9$ & $52.5 \pm 4.2$ \\
5.0\% starch, 0.50\% urea & $3.3 \pm 0.1$ & $19.9 \pm 2.1$ & $19.4 \pm 1.0$ & $39.2 \pm 0.3$ & $51.0 \pm 0.1$ \\
Corn silage & $3.6 \pm 0.5$ & $7.8 \pm 0.5$ & $4.5 \pm 0.4$ & $26.5 \pm 4.1$ & $49.8 \pm 7.0$ \\
Alfalfa hay & $8.3 \pm 0.9$ & $16.7 \pm 2.3$ & $1.9 \pm 0.5$ & $31.6 \pm 3.4$ & $43.3 \pm 3.8$ \\
Concentrate & $11.3 \pm 0.9$ & $26.9 \pm 0.4$ & $3.4 \pm 1.0$ & $5.2 \pm 0.3$ & $19.2 \pm 2.5$ \\
\hline
\end{tabular}

${ }^{1}$ All data are expressed as mean $1 \mathrm{SD}$.

${ }^{2} \mathrm{EE}=$ ether extract.

\section{RESULTS AND DISCUSSION}

The chemical composition of the control and coated WCS are presented in Table 2. A slight decrease in the concentration of most nutrients was observed for the coated WCS due to dilution by starch and urea compared with control. The composition of corn silage and alfalfa was typical for these forages at this location. Composition of the concentrate is in agreement with formulated values. No differences were observed in the chemical composition of the experimental diets (Table 3 ), which were consistent with formulated values.

Ruminal $\mathrm{pH}(P<0.05)$ and molar proportions of isobutyrate $(P<0.02)$ were higher, whereas concentrations of $\mathrm{NH}_{3}-\mathrm{N}$ tended to be lower $(P<0.07)$ for control compared with WCS coated with starch and urea (Table 4). Molar proportions of propionate tended to be higher $(P$ $<0.06)$ and valerate was lower $(P<0.03)$ for $2 \mathrm{~S}$ compared with 5S. Concentrations of total VFA were numerically higher for $5 \mathrm{~S}$ compared with $2 \mathrm{~S}$, but differ-

Table 3. Composition experimental diets containing whole cottonseed coated with combinations of gelatinized corn starch and urea.

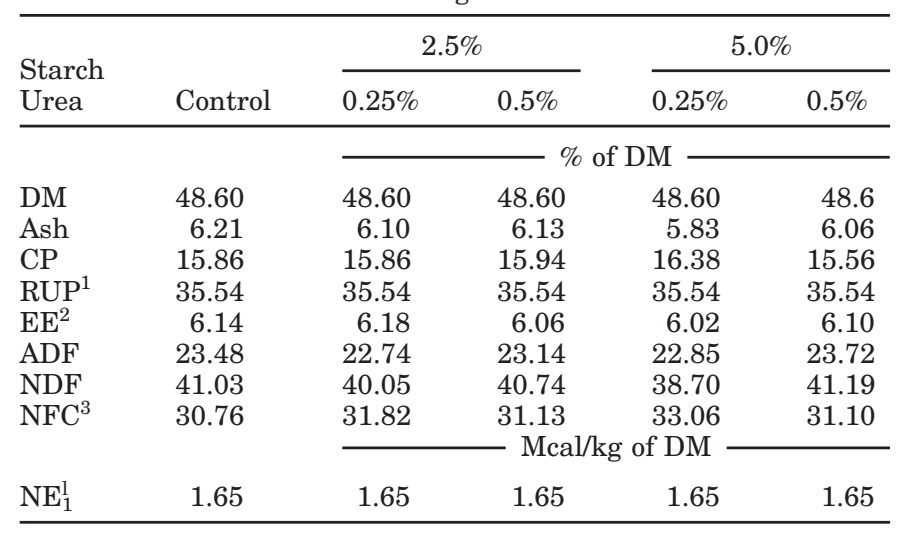

${ }^{1}$ Calculated using NRC (1989) values.

${ }^{2} \mathrm{EE}=$ ether extract.

${ }^{3} \mathrm{NFC}=$ nonfiber carbohydrates $(100-($ Ash $+\mathrm{CP}+\mathrm{EE}+\mathrm{NDF})$. ences were not significant $(P=0.12)$. Molar proportions of acetate tended to be higher $(P<0.07)$ and butyrate was lower $(P<0.01)$ for $2 \mathrm{U}$ compared with $5 \mathrm{U}$. There was an interaction between starch and urea for molar proportions of isovalerate $(P<0.01)$ and serum urea $\mathrm{N}$ concentrations $(P<0.10)$ due to higher values for $5 \mathrm{~S} 5 \mathrm{U}$ compared with 5S2U. No differences were observed in concentrations of total VFA or serum glucose.

Coating WCS with starch has been observed to decrease in vitro ruminal $\mathrm{pH}$ and molar proportions of acetate and butyrate and increase concentrations of total VFA and molar proportions of propionate (Bernard et al., 2001). The small amount of starch contributed by the coating applied to WCS would not be expected to alter total VFA concentrations or molar proportions significantly. Inclusion of urea in the starch coating increased in vitro $\mathrm{pH}$, concentrations of $\mathrm{NH}_{3}-\mathrm{N}$, and molar proportions of butyrate (Bernard et al., 2001). The reduction in molar proportions of isobutyrate suggests reduced fermentation of lysine for WCS coated with starch and urea. Lysine is considered to be the most limiting amino acid in WCS; thus, this aspect needs additional investigation to determine the impact of coating on amino acid digestion.

There were no differences in nutrient intake among control and coated WCS, but an interaction was observed between starch and urea levels (Table 5). Cows fed the diet containing 5S5U consumed less DM $(P<$ $0.05)$, OM $(P<0.05)$, ether extract $(P<0.06)$, and NDF $(P<0.07)$ than when fed the diet containing 2S5U. There were no differences among treatments in ruminal and total tract apparent digestibility of $\mathrm{DM}, \mathrm{OM}$, and ether extract. There was a tendency $(P<0.10)$ for increased ruminal NDF digestibility when WCS were coated with $0.5 \%$ urea, but total tract NDF digestibility was similar for all treatments.

Total track NDF digestibility was depressed when WCS were coated with either 5\% starch or 5\% starch plus $10 \%$ maltodextrin sugar and fed at $15 \%$ of the 
Table 4. Concentrations of metabolites in ruminal fluid and serum of cows fed diets containing whole cottonseed coated with combinations of gelatinized corn starch and urea.

\begin{tabular}{|c|c|c|c|c|c|c|c|c|c|c|}
\hline \multirow{2}{*}{$\begin{array}{l}\text { Starch } \\
\text { Urea }\end{array}$} & \multirow[b]{2}{*}{ Control } & \multicolumn{2}{|c|}{$2.5 \%$} & \multicolumn{2}{|c|}{$5.0 \%$} & \multirow[b]{2}{*}{$\mathrm{SE}$} & \multicolumn{4}{|c|}{ Contrast $^{1}$} \\
\hline & & $0.25 \%$ & $0.5 \%$ & $0.25 \%$ & $0.5 \%$ & & 1 & 2 & 3 & 4 \\
\hline \multicolumn{11}{|l|}{ Ruminal metabolites } \\
\hline $\mathrm{pH}$ & 6.46 & 6.35 & 6.37 & 6.37 & 6.31 & 0.05 & 0.05 & $\mathrm{NS}^{2}$ & NS & NS \\
\hline $\mathrm{NH}_{3}-\mathrm{N}, \mathrm{mg} / \mathrm{dl}$ & 9.43 & 10.66 & 11.60 & 11.86 & 11.21 & 0.90 & 0.07 & NS & NS & NS \\
\hline Total VFA, Mm & 53.51 & 53.34 & 54.64 & 59.10 & 62.51 & 2.83 & NS & NS & NS & NS \\
\hline Acetate & 56.47 & 57.95 & 55.49 & 58.56 & 57.60 & 0.92 & NS & NS & 0.07 & NS \\
\hline Propionate & 23.53 & 23.46 & 24.76 & 23.15 & 22.61 & 0.66 & NS & 0.06 & NS & NS \\
\hline Butyrate & 11.75 & 11.74 & 13.29 & 11.89 & 12.53 & 0.40 & NS & NS & 0.01 & NS \\
\hline Isobutyrate & 4.37 & 2.80 & 2.67 & 2.63 & 2.56 & 0.62 & 0.02 & NS & NS & NS \\
\hline Isovalerate & 2.25 & 2.34 & 2.17 & 1.96 & 2.80 & 0.20 & NS & NS & 0.10 & 0.01 \\
\hline Valerate & 1.63 & 1.71 & 1.63 & 1.81 & 1.91 & 0.08 & NS & 0.03 & NS & NS \\
\hline \multicolumn{2}{|l|}{ Serum metabolites } & & -1 & 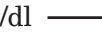 & & & & & & \\
\hline Glucose & 64.53 & 63.04 & 63.44 & 63.60 & 65.71 & 2.08 & NS & NS & NS & NS \\
\hline Urea N & 15.25 & 16.80 & 16.84 & 14.91 & 17.66 & 0.68 & NS & NS & 0.09 & 0.10 \\
\hline
\end{tabular}

${ }^{1}$ Contrast: $1=$ control versus coated WCS; $2=2.5$ versus $5.0 \%$ starch; $3=0.25$ versus $0.5 \%$ urea; $4=$ interaction of starch and urea in coating applied to WCS.

${ }^{2}$ Not significant $(P>0.10)$.

dietary DM (Bernard et al., 1999). Cellulose digestion has been shown to decrease in the presence of a rapidly fermentable carbohydrate (Stern et al., 1978). The lint on WCS is primarily cellulose, and coating WCS with starch would potentially increase the number of amylolytic microorganisms in preference to cellulolytic microorganisms. Cellulolytic microorganisms use $\mathrm{NH}_{3}-\mathrm{N}$ as their primary source of $\mathrm{N}$ for growth (Polan et al., 1976). Although diets in the current study were not limiting in $\mathrm{NH}_{3}-\mathrm{N}$, inclusion of urea in the coating would provide a readily available source of $\mathrm{NH}_{3}-\mathrm{N}$, which would increase the $\mathrm{pH}$ around the WCS lint and stimulate cellulolytic activity (Archimède et al., 1999). An increase in partial pressure of $\mathrm{H}_{2}$ has been shown to contribute to reduced NDF digestibility in vitro (Piowonka and Firkins, 1996). In vitro concentrations of $\mathrm{H}_{2}$ increased as the starch increased from 0 to $5 \%$ in coated WCS (Bernard et al., 1999, 2001), but it is not apparent if this was a factor in the current trial since $\mathrm{H}_{2}$ was not measured.

Table 5. Nutrient intake and apparent digestibility of cows fed diets containing whole cottonseed coated with combinations of gelatinized corn starch and urea.

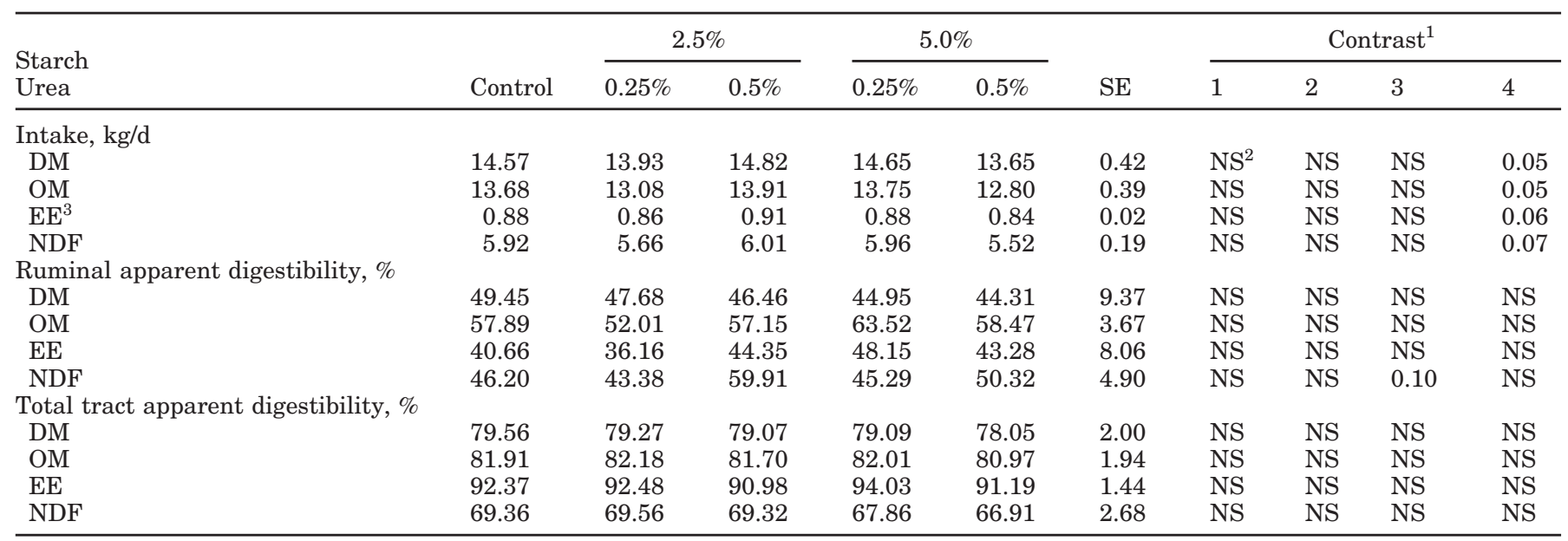

\footnotetext{
${ }^{1}$ Contrast: $1=$ control versus coated WCS; $2=2.5$ versus $5.0 \%$ starch; $3=0.25$ versus $0.5 \%$ urea; $4=$ interaction of starch and urea in coating applied to WCS.

${ }^{2}$ Not significant $(P>0.10)$.

${ }^{3} \mathrm{EE}=$ ether extract.
} 
Table 6. Nitrogen flow and apparent digestibility of cows fed diets containing whole coated cottonseed with combinations of gelatinized corn starch and urea.

\begin{tabular}{|c|c|c|c|c|c|c|c|c|c|c|}
\hline $\begin{array}{l}\text { Starch } \\
\text { Urea }\end{array}$ & Control & \multicolumn{2}{|c|}{$2.5 \%$} & \multicolumn{2}{|c|}{$5.0 \%$} & $\mathrm{SE}$ & \multicolumn{4}{|c|}{ Contrast $^{1}$} \\
\hline $\begin{array}{l}\text { Intake, g/d } \\
\text { Duodenal flow, g/d }\end{array}$ & 348.2 & 331.4 & 352.4 & 350.1 & 323.2 & 10.3 & NS & NS & NS & 0.05 \\
\hline Total & 239.3 & 252.4 & 265.7 & 255.8 & 222.7 & 28.7 & NS & NS & NS & NS \\
\hline Bacterial & 110.5 & 96.0 & 153.1 & 125.7 & 143.0 & 23.9 & NS & NS & NS & NS \\
\hline Nonbacterial & 128.8 & 156.4 & 112.6 & 130.1 & 79.7 & 21.4 & NS & NS & 0.06 & NS \\
\hline Total tract apparent digestibility, \% & 70.7 & 69.3 & 71.2 & 70.0 & 67.4 & 2.6 & NS & NS & NS & NS \\
\hline
\end{tabular}

${ }^{1}$ Contrast: $1=$ control versus coated WCS; $2=2.5$ versus $5.0 \%$ starch; $3=0.25$ versus $0.5 \%$ urea; $4=$ interaction of starch and urea in coating applied to WCS.

${ }^{2}$ Not significant $(P>0.10)$.

Nitrogen intake, flow, and apparent digestibility data are presented in Table 6 . An interaction between starch and urea was noted for $\mathrm{N}$ intake due to higher $(P<$ $0.04) \mathrm{N}$ intake for $2 \mathrm{~S} 5 \mathrm{U}$ compared with $5 \mathrm{~S} 5 \mathrm{U}$. Total $\mathrm{N}$ flow to the duodenum was similar for all treatments. The flow of bacterial $\mathrm{N}$ was numerically higher for WCS coated with $5 \mathrm{U}$, but these differences were not significant $(P=0.16)$. The flow of nonbacterial $\mathrm{N}$ tended to be lower $(P<0.06)$ for WCS coated with $5 \mathrm{U}$ compared with 2U. Apparent ruminal N digestibility was similar for all treatments and averaged 38.1\%. Apparent and true efficiencies of bacterial protein synthesis were similar for all treatments. The efficiency of bacterial protein synthesis is within the range of values reported by Clark et al. (1992). No differences were observed in total tract apparent digestibility of $\mathrm{N}$, which averaged $69.7 \%$.

Archimède et al. (1999) reported increased flow of $\mathrm{N}$ to the duodenum and higher efficiency of bacterial $\mathrm{N}$ synthesis when diets were supplemented with urea, but did not observe any differences when diets were supplemented with sugar. However, Cameron et al. (1991) did not observe any difference in $\mathrm{N}$ flow to the duodenum when diets were supplemented with urea or starch. Large differences would not be expected in total or bacterial $\mathrm{N}$ flow to the small intestine given the small amount of starch and urea used to coat the WCS.

\section{CONCLUSIONS}

Coating WCS with combinations of starch and urea appears to slightly alter ruminal fermentation. Other than a trend for increased NDF digestibility with $0.5 \%$ urea in the coating, the coating does not alter ruminal or total tract apparent digestibility of nutrients. Coating WCS with starch and urea did not increase total N flow to the duodenum. Results of this trial indicate that WCS coated with combinations of starch and urea digested equally as well as uncoated WCS.

\section{ACKNOWLEDGMENTS}

Funding for this research was provided by the Georgia Cotton Commission and the University of Georgia Agricultural Experiment Station. Appreciation is extended to the staff at the Tifton Dairy Research center for assistance with feeding and animal care and to Melissa Tawzer and Elaine Miller for assistance with chemical analyses.

\section{REFERENCES}

Archimède, H., G. Aumont, G. Saminadin, E. Deprès, P. Despois, and A. Xandè. 1999. Effects of urea and saccharose on intake and digestion of a Digitaria decumbens hay by black belly sheep. Anim. Sci. 69:403-410.

Association of Official Analytical Chemist. 1990. Official Methods of Analysis. Vol. I. 15th ed. AOAC, Arlington, VA.

Bernard, J. K. 1999. Performance of lactating dairy cows fed whole cottonseed coated with gelatinized corn starch. J. Dairy Sci. 82:1305-1313.

Bernard, J. K., M. C. Calhoun, and S. A. Martin. 1999. Effect of coating whole cottonseed on performance of lactating dairy cows. J. Dairy Sci. 82:1296-1304.

Bernard, J. K., S. A. Martin, and T. C. Wedegaertner. 2001. In vitro mixed ruminal microorganism fermentation of whole cottonseed coated with gelatinized corn starch and urea. J. Dairy Sci. 84:154-158.

Brisson, G. J. 1956. On routine determination of chromic oxide in feces. Can. J. Agric. Sci. 36:210-212.

Cameron, M. R., T. H. Klusmeyer, G. L. Lynch, J. H. Clark, and D. R. Nelson. 1991. Effects of urea and starch on rumen fermentation, nutrient passage to the duodenum, and performance of cows. J. Dairy Sci. 74:1321-1336.

Clark, J. H., T. H. Klusmeyer, and M. R. Cameron. 1992. Microbial protein synthesis and flows of nitrogen fractions to the duodenum of dairy cows. J. Dairy Sci. 75:2304-2323.

Laird, W., T. C. Wedegaertner, and T. D. Valco. 1997. Coating cottonseed for improved handling characteristics. Pages 1599-1602 in 
Proc. Beltwide Cotton Conf., New Orleans, LA. Natl. Cotton Council. Am., Memphis, TN.

Miron, J., D. Ben-Ghedalia, and M. Morrison. 2001. Invited Review: Adhesion mechanisms of rumen cellulolytic bacteria. J. Dairy Sci. 84:1294-1309.

Piwonka, E. J., and J. L. Firkins. 1996. Effect of glucose fermentation on fiber digestion by ruminal microorganisms in vitro. J. Dairy Sci. 79:2196-2206.

Polan, C. E., C. N. Miller, and M. L. McGillard. 1976. Variable dietary protein and urea for intake and production in Holstein cows. J. Dairy Sci. 59:1910-1914.

SAS. 1999. SAS/STAT User's Guide, Version 8. SAS Inst., Inc., Cary, NC.
Stern, M. D., H. Hoover, C. J. Sniffen, B. A. Cooker, and P. H. Knowlton. 1978. Effects of nonstructural carbohydrate, urea, and soluble protein levels on microbial protein synthesis in continuous culture of rumen contents. J. Anim. Sci. 47:944-956.

Supelco Bull. 7498. 1975. GC separation of VFA C2 - C25. Supelco, Bellefonte, PA.

Van Soest, P. J., J. B. Robertson, and B. A. Lewis. 1991. Methods for dietary fiber, neutral detergent fiber, and nonstarch polysaccharides in relation to animal production. J. Dairy Sci. 74:3583-3597.

Zinn, R. A., and F. N. Owens. 1986. A rapid procedure for purine measurement and its use for estimating net ruminal protein synthesis. Can. J. Anim. Sci. 66:157-166. 